\title{
Oxygenated additives in bio-fuels: excess enthalpies of mixtures di-butyl ether + 1-propanol + heptane or + cyclohexane at 298.15 and $313.15 \mathrm{~K}$
}

\author{
F.E.M. Alaoui ${ }^{1,2}$, F. Aguilar ${ }^{1}$, M.J. González-Fernández ${ }^{1}$, A. El Amarti ${ }^{2}$, and E. Montero ${ }^{1}$ \\ ${ }^{1}$ Departamento de Ingenier a Electromecánica, Universidad de Burgos, Burgos, Spain \\ ${ }^{2}$ Department of Chemistry, Abdelmalek Essaâdi University, Tetouan, Morocco
}

The increasing worldwide use of bio-fuels constitutes one of the measures considered to reduce greenhouse gas emissions. Bio-fuels also have an important part to play in promoting the security of energy supply, and promoting technological development and innovation. Di-butyl ether (DBE) is used as blending agent in reformulated gasoline and has been included in recent international regulations on the promotion of the use of energy from renewable sources for transport [1]. Recently 1-propanol has been proposed too as an alternative to conventional gasoline and diesel fuels [2]. Interest in propanols as a second-generation biofuels has increased because they have many advantages over other potential alternative fuel candidates such as ethanol, as they can be produced from biomass by microbial fermentation of biomass (cellulose).

Ether + alcohol + alkane mixtures are of interest as model mixtures for gasoline in which the alcohol and the ether act as non-polluting, high octane number blending agents. From this point of view the study of the ternary mixtures dibutyl ether +1-propanol and heptane, or cyclohexane, are very interesting. This work is a new contribution to previous works on ether + alcohol + alkane mixtures of our group [3-7].

Experimental excess enthalpies of the ternary systems $\mathrm{DBE}+1$-propanol + heptane or + cyclohexane and the corresponding binary systems at $298.15 \mathrm{~K}$ and $313.15 \mathrm{~K}$ are reported in this work. Excess enthalpies have been measured with a quasi-isothermal flow calorimeter.

The experimental data have been fitted using the RedlichKister polynomial equation for binary and ternary systems. The values of the standard deviation indicate the agreement between the experimental results and the fitted ones. Excess enthalpies have been determined with an estimated relative uncertainty of $+0.01 \cdot \mathrm{H}^{\mathrm{E}} \mathrm{J} \cdot \mathrm{mol}-1$ at 298.15 and $313.15 \mathrm{~K}$.

We acknowledge support for this research to the Ministerio de Ciencia e Innovación, Spain, Project ENE2009-14644-C02-02 and to the Agencia Española de Cooperación Internacional para el Desarrollo AECID, project AP/041072/11. This work is part of the Doctoral Thesis of F.E.M. Alaoui.

\section{References}

1. Directive 2009/28/EC of the European Parliament ad of the Council on the promotion of the use of energy from renewable sources

2. R. Luque, J. Campelo, J. Clark, Handbook of biofuels production: Processes and technologies, Woodhead Publishing Series in Energy No 15, Cambridge, UK (2011)

3. F. Aguilar, F.E.M. Alaoui, J.J. Segovia, M.A. Villamañán, E.A. Montero, J. Chem. Eng. Data 541672 (2009)

4. F. Aguilar, F.E.M. Alaoui, J.J. Segovia, M.A. Villamañán, E.A. Montero, Fluid Phase Equilib. 284 106 (2009)

5. F. Aguilar, F.E.M. Alaoui, J.J. Segovia, M.A. Villamañán, E.A. Montero. Fluid Phase Equilib. 29015 (2010)

6. F. Aguilar, F.E.M. Alaoui, J.J. Segovia, M.A. Villamañán, E.A. Montero, J. Chem. Thermodyn. 4228 (2010)

7. F. Aguilar, F.E.M. Alaoui, J.J. Segovia, M.A. Villamañán, E.A. Montero, Fluid Phase Equilib. 3151 (2012) 